\title{
Vertical Dimension of Occlusion: A comparative study between Anthropometric and Knebelman's craniometric methods
}

\author{
Francisco Avila-Vásquez, Paúl Vergara-Sarmiento, Cristina Crespo-Crespo \\ Universidad Católica de Cuenca, Facultad de Odontología, Azogues, Ecuador.
}

\begin{abstract}
The masticatory system changes as time passes. The vertical dimension of occlusion (VDO) undergoes alterations due to temporomandibular joint disorders which in turn may be caused by related muscle modifications or pathological tooth wear. There are many methods to measure VDO. Among these, the anthropometric method and Knebelman's craniometric method have been shown to be the most closely related to facial biotype. The aim of this study was to compare data recorded with those two methods. A descriptive cross-sectional study was performed with a total 200 patients. A vernier caliper was used to
\end{abstract}

measure facial landmarks. Results were analyzed using paired $t$-test, setting the level of significance at $p<0.05$. There was no significant difference between the two methods but Knebelman's method had less variability. Results suggest that Knebelman's method should provide more reliability for determining VDO in all the facial biotypes studied.

Received: June 2020; Accepted: February 2021

Keywords: vertical dimension - dental occlusion temporomandibular joint.

\section{Dimensión vertical oclusal: un estudio comparativo entre el método antropométrico y el método craneométrico de Knebelman}

\begin{abstract}
RESUMEN
El sistema masticatorio cambia con el paso del tiempo. La dimensión vertical oclusal sufre alteraciones que se atribuyen a trastornos temporomandibulares a su vez causados por modificaciones en la musculatura relacionada o al desgaste patológico de las piezas dentarias. Existen muchos métodos para medir la dimensión vertical, entre los cuales el método antropométrico y el método craneométrico de Knebelman mostraron ser los más vinculados con el biotipo facial. El objetivo de este estudio fue comparar datos registrados con ambos métodos. La comparación fue realizada mediante un estudio de diseño transversal descriptivo con un total de 200 pacientes, usando un calibrador vernier para realizar
\end{abstract}

\section{INTRODUCTION}

A consequence of advancing age is the presence of alterations in the masticatory system which involve maxillary, mandible, temporomandibular joint (TMJ) and musculature. Within the latter, the masseter muscle determines the vertical dimension of occlusion (VDO) stabilization. Thus, any degradation involving those structures derives in a functional decompensation ${ }^{1-3}$.

It is currently known that TMJ alterations are not the only cause of occlusion disorders. Temporo mediciones entre puntos faciales establecidos. Los resultados fueron analizados por medio de la prueba de t de Student para datos emparejados estableciendo el nivel de significación en $P<0,05$. No se encontró diferencia significativa entre los métodos, pero el método de Knebelman mostró generar menos variabilidad en sus medidas. Este último método parece proporcionar más confiabilidad para su aplicación en la determinación de la dimensión vertical oclusal en todos los biotipos faciales estudiados.

Palabras clave: dimensión vertical - oclusión dental articulación temporomandibular.

mandibular disorders (TMD) related to changes in vertical dimensions with modified functioning of surrounding muscles generate a posterior position in the condyle that can be established using conebeam computed tomography $(\mathrm{CBCT})^{4-7}$. Some of these alterations are caused by alveolar ridge resorption and changes in biting forces that modify condyle positions inside the articular fossa ${ }^{8}$. Those changes are related to increased mechanical tooth surface wear and may progress to pathological tooth 
wear (PTW) because of parafunctional mandibular movements which modify masticatory muscle tone, and generate facial pain and aesthetic and phonetic disorders ${ }^{8-14}$.

These alterations plus missing teeth lead to decreased or increased VDO, which is visualized by changes in the distance between the nasal spine (Subnasale, "Sn") and the most anterior inferior point of the chin (Soft Tissue Menton, "Me"). When the mandible is in physiologic rest position with non-contacting teeth, it is called rest vertical dimension (RVD), which differs from VDO ${ }^{15-17}$.

Many methods have been suggested over the past decades to establish VDO: swallowing, phonetic, rest position, maximum closing force, pre-extraction records, Willis, Landa, McGee, Hayakawa, comfort, cephalometric, anthropometric and Knebelman's craniometric method, but none of them can register VDO objectively. Original specifications suggest that Knebelman's method should be applied in normal craniofacial development (mesoprosopic). Later studies found a correlation with leptoprosopic type because of racial characteristics, but they emphasize that there is no applicability for euryprosopic ${ }^{18-28}$. Ricketts defined facial biotype as the morphologic and functional characteristics of the face, reason why, facial biotype is used for treatment plans which depends on the maxillary facial growth pattern ${ }^{29}$ where biting force, has been shown to be related to final dental arch form ${ }^{30}$.

This study evaluated the VDO determinations obtained by anthropometric and Knebelman's craniometric methods.

\section{MATERIALS AND METHODS}

A cross-sectional study was performed with 200 adults, selected from patients attending Catholic University of Cuenca dental clinics located in Azogues, Ecuador. Each participant completed an informed consent form. Bioethical and technical aspects of the project were approved by the Catholic University of Cuenca - Azogues authorities under code 00001CIABEOSA.

Demographics (age, sex) and clinical data (edentulism type and facial biotype) were recorded. Trained, calibrated $(\mathrm{Kappa}=0.8)$ clinicians used both the anthropometric method and Knebelman's craniometric method to determine VDO in all participants. The procedure was conducted under natural light. Patients sat with a straight back.
Frankfort plane was established parallel to the floor, occluding for partially dentate patients and reaching rest position for edentulous patients. Once these positions were obtained, anthropometric points were marked using an eye pencil. Facial index was determined using the Mayoral index that uses soft tissues related landmark points (ophryonmenton/zygion-zygion) to register measurements in millimeters. This enabled the distribution of facial types within the sample to be established.

The anthropometric method was applied using a vernier caliper to determine the planes mentioned in Table 1. The measurements were compared to the height of the lower facial third. $A \pm 2 \mathrm{~mm}$ error range between measures was set to define whether vertical dimension was maintained, diminished or increased (Figs. 1 and 2).

Knebelman's Craniometric method was applied using a Knebelman's craniometer, which only considers two measurements, called "READ", from external auditory canal to the lateral corner of the bony orbit and "SET" from Sn (subnasal) to the most anterior undersurface of mandible. Both readings are correlated and contribute to the final result (Figs. 3 and 4).

A template was designed on which to record the measurements, allowing selection of measurements not to be considered for the anthropometric method (Table 1).

Statistical analysis was performed by obtaining averages and standard deviation, and differences between the methods were analyzed using the t-test for paired data. Significance level was established at $\mathrm{P}<0.05$.

\section{RESULTS}

Tables 2 and 3 show distribution of sex and age, respectively, and tables 4 and 5 show distribution of edentulism type and facial biotype, respectively.

The application of the t-test for paired data showed a significant difference $(p<0.001)$ between the two methods (Table 6).

When facial type is considered (Table 7) the difference between methods was not statistically significant in leptoprosopic patients, though it was significant in the other two groups.

\section{DISCUSSION}

Losing natural dentition can lead to alterations in the height of the lower facial third due to increased bite 


\section{Table 1. Template to record the measurements of each patient}

\section{VERTICAL DIMENSION OF OCCLUSSION MEASUREMENTS}

\section{Measurements}

\section{Anthropometric Method}

Chosen measures

Knebelman Method

1. Eye outer Cantus -Tragus (mm)

\section{Bipupilar}

3. Eye outer Cantus - outer comissure $(\mathrm{mm})$

\section{FACIAL THIRDS}

- Trichion - Glabela

- Glabela - Subnasale

- Subnasale- Menton

Mean $(\mathrm{mm})$

\section{FACIAL BIOTYPE DETERMINATION}

(MAYORAL INDEX)

Glabela- Menton

Bicigomátic distance

(Zygion - Zygion)
* Leptoprosopic (>104 mm)

* Mesoprosopic (97-104 mm)

* Euriprosopic (<97mm)

Mean (mm)

force, so reestablishing VDO improves quality of life by enabling the patient to recover the ability to produce certain movements without any limitation. It is thus important for dentists to obtain precise measurements for an adequate VDO. Ayoub ${ }^{28}$ reports that interpupillary distance can be used as a VDO determination factor in males. Alhajj, et $\mathrm{al}^{29}$ report that measurements from the outer canthus of the eye to the oral commissure are more

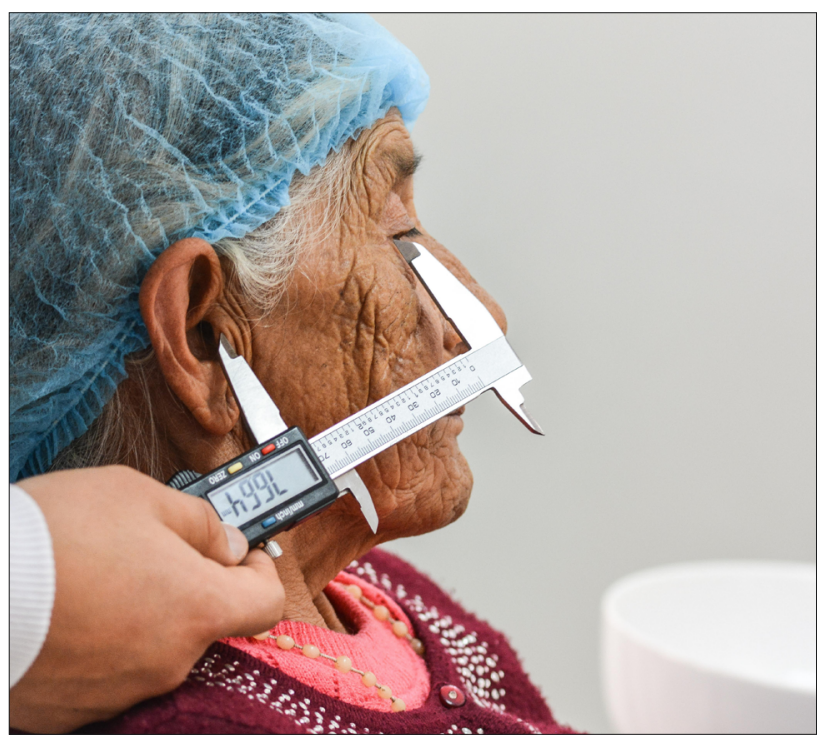

Fig. 1: Anthropometric method application (Eye outer canthusTragus measurement delimitation)

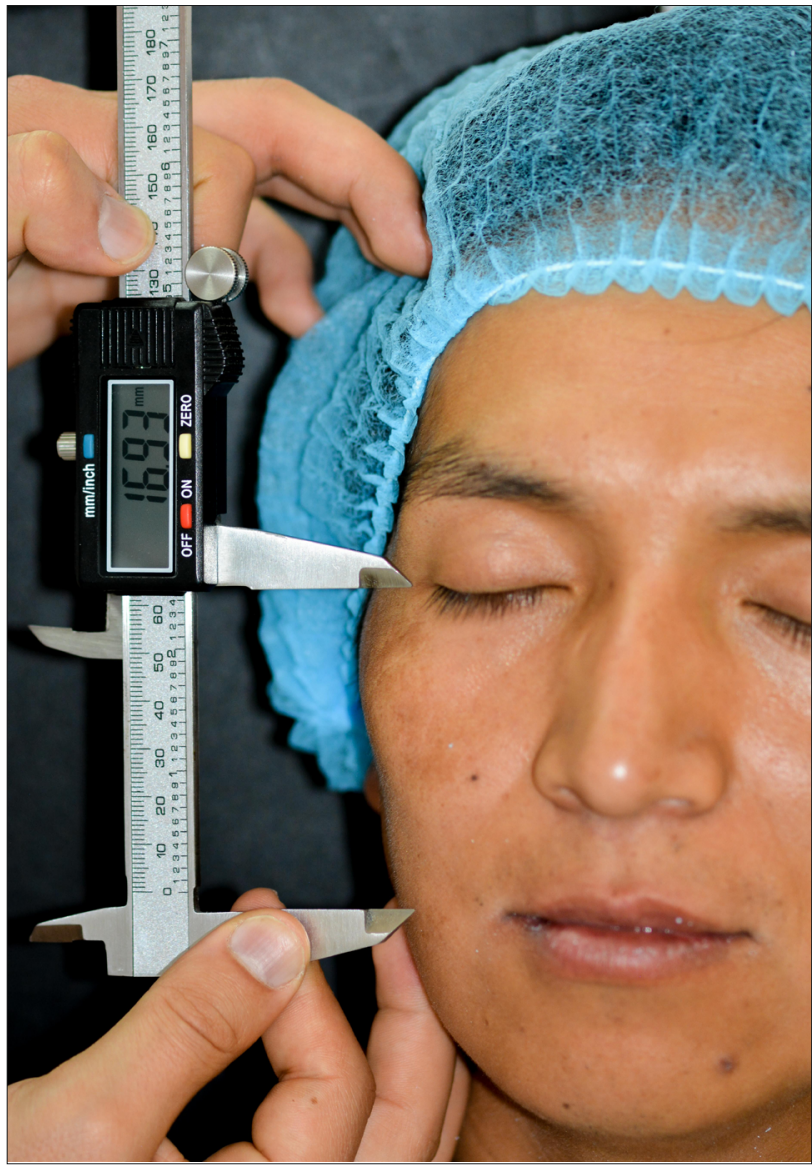

Fig. 2: Anthropometric method application (Eye outer CanthusOuter commissure measurement delimitation) 


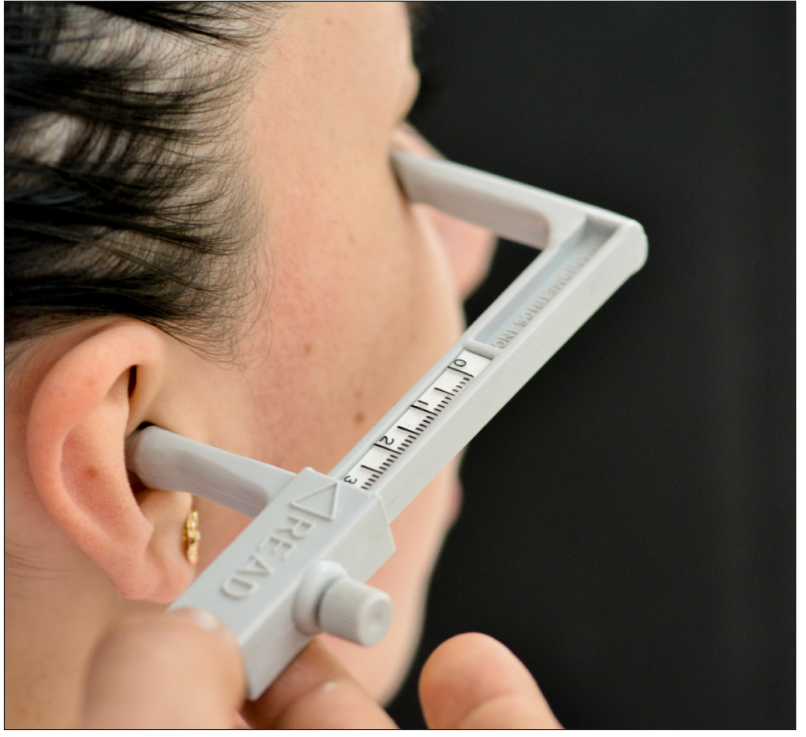

Fig. 3: Knebelman's craniometric method (Read position application)

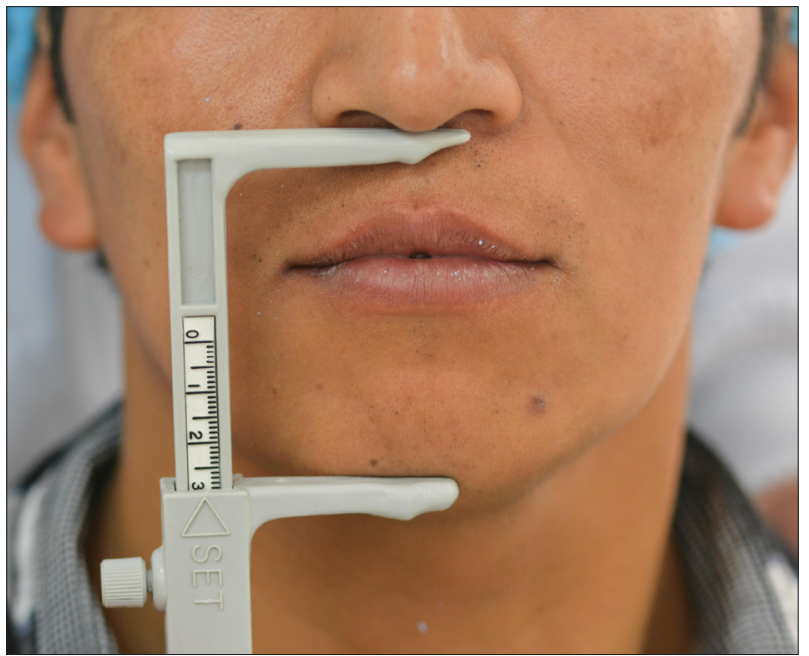

Fig. 4: Knebelman's craniometric method (Set position application)

reliable for VDO prediction for edentulous patients. According to Bajunaid et al..$^{30}$, facial landmarks mentioned by Misch (about 12 measurements with a difference range between $1-2 \mathrm{~mm}$ ) are used to determine VDO in edentulous patients reliably and objectively. Distances between left eye-ear and left angle of the eye to angle of mouth showed accuracy in determining VDO for complete denture wearers, as is also mentioned by Majeed et $\mathrm{al}^{31}$. The Constantiniuc $^{32}$ comparison between phonetic, rest position and anthropometric methods to establish VDO did not show relevant differences between final measurements, which suggests that these methods could be applied to help determine VDO in
Table 2. Sample distribution according to gender

\begin{tabular}{|c|c|c|}
\hline GENDER & $\boldsymbol{N}$ & $\%$ \\
\hline Male & 53 & 27 \\
\hline Female & 147 & 73 \\
\hline TOTAL & 200 & 100 \\
\hline
\end{tabular}

Table 3. Sample distribution according to age AGE GROUP (years)

17-25

N $\quad \%$

26-40

30

15

41-60

$31 \quad 15$

$>61$

72

36

TOTAL

67

200

34

100

Table 4. Sample distribution according to edentulism type

TYPE

\begin{tabular}{|r|r|}
\hline $\boldsymbol{N}$ & $\%$ \\
\hline 139 & 70 \\
\hline 61 & 30 \\
\hline 200 & 100 \\
\hline
\end{tabular}

\section{Table 5. Sample distribution according to facial} biotype

\begin{tabular}{|c|c|r|}
\hline BIOTYPE & $\boldsymbol{n}$ & $\%$ \\
\hline Leptoprosopic & 77 & 38 \\
\hline Mesoprosopic & 98 & 49 \\
\hline Euriprosopic & 25 & 13 \\
\hline TOTAL & 200 & 100 \\
\hline
\end{tabular}

edentulous patients. However, according to Batra ${ }^{33}$, there is no validation for any method proposed to measure VDO. The use of bone points by cephalometric analysis leads to increased accuracy in measurements because there is no facial or positional manipulation determining freeway space, but a functional method must also be used to improve measurements provided by lateral RX in edentulous patients. Ousehal and Sierpinska ${ }^{34,35}$ report that cephalometric studies could lead to an adequate initial VDO, referring to Knebelman's craniometer as an adequate way to determine initial VDO that could be complemented with cephalometric studies. One of the most frequently analyzed concerns is considered by Behrensdorf ${ }^{36}$, who says that age and time using dentures affect VDO reestablishment and mandibular movements. According to these conclusions, Fukushima ${ }^{37}$ evaluated methods based on condyle position and showed their unreliability due to the effect of muscle action on it. Watarai ${ }^{38}$ 
Table 6. T test between anthropometric method and Knebelman's craniometric method applied in treated patients.

\begin{tabular}{|l|c|c|c|c|}
\hline \multicolumn{1}{|c|}{ METHOD } & Mean & St. Dev. & Mean difference & p value* \\
\hline Anthropometric & 64.18 & 5.06 & -1.28 & $<0,001$ \\
\hline Knebelman's craniométric & 65.26 & 3.78 & & \\
\hline${ }^{*} \mathrm{Cl}(\mathbf{9 5 \% )}$ for the mean difference $=-1.660 /-0.50$ & & &
\end{tabular}

\begin{tabular}{|c|c|c|c|c|c|}
\hline \multirow[t]{2}{*}{ BIOTYPE } & \multicolumn{2}{|c|}{$\begin{array}{l}\text { ANTHROPOMETRIC } \\
\text { METHOD }\end{array}$} & \multicolumn{2}{|c|}{$\begin{array}{c}\text { KNEBELMAN'S CRANIOMETRIC } \\
\text { METHOD }\end{array}$} & \multirow[t]{2}{*}{ P value } \\
\hline & MEAN & SD & MEAN & SD & \\
\hline Leptoprosopic & 66.55 & 4.99 & 66.77 & 3.50 & 0.750 \\
\hline Mesoprosopic & 63.19 & 4.54 & 64.52 & 3.53 & 0.023 \\
\hline Euriprosopic & 60.8 & 4.07 & 63.60 & 4.12 & 0.019 \\
\hline
\end{tabular}

states that physiologic mandibular rest position could be modified by head or body postures, mental state, muscles and TMJ, emphasizing the difficulties in establishing an accurate position.

On the other hand, Miran ${ }^{39}$ claims that the applicability of a specific method to determine VDO depends on accuracy, adaptability, equipment and cost. However, Mahboub ${ }^{40}$ states that differences in their application using stone casts, pre-extraction records or cephalograms help in the determination of VDO but are not reliable by themselves.

In addition, some studies showed compatibility with the results obtained in the current study. Talavera ${ }^{18}$ compared Willis and McGee methods (using craniometrical measures such as Knebelman's).

\section{DECLARATION OF CONFLICTING INTERESTS}

The authors declared no potential conflicts of interest with respect to the research, authorship, and/or publication of this article.

\section{FUNDING}

None

\section{REFERENCES}

1. Al-Saleh MA, Punithakumar K, Lagravere M, Boulanger P, Jaremko JL, Wolfaardt J, Major PW, Seikaly H. Three-dimensional morphological changes of the temporomandibular joint and functional effects after mandibulotomy. J Otolaryngol Head Neck Surg. 2017;46:8. doi: 10.1186/s40463-017-0184-4.

2. Ghassemian M, Lajolo C, Semeraro V, Giuliani M, Verdugo
Alhajj ${ }^{29}$ using a method that involves a finger length shaft, obtained mean measurements that are within the range of values recorded in our study. This information suggests the reliability of the method in different scenarios.

After studying and recording facial biotype and VDO, our results showed a small difference between mean measurements obtained with the two methods under study. Knebelman's craniometric method seems to be more reliable during the VDO determination process since its variability is lower. It is also easier to apply and reduces diagnosis time. One of its possible disadvantages may be the cost of the instrument. This is the first local study to record VDO and facial biotype, so it could be used as a baseline for further studies.

\section{CORRESPONDENCE:}

Dr. Francisco E. Avila Vásquez

Calle. Jaime Roldos \& 4 de noviembre.

Cañar-Ecuador

avila_pancho@hotmail.com
F, Pirronti T, D'Addona A. Relationship Between Biotype and Bone Morphology in the Lower Anterior Mandible: An Observational Study. J Periodontol. 2016;87:680-689. doi:10.1902/jop.2016.150546.

3. Real Aparicio MC. Disfunción temporomandibular: causas y tratamientos. Revista del Nacional (Itauguá). 2016;10:68-91. URL: https://dx.doi.org/10.18004/rdn2018. 0010.01.068-091. 
4. Ramírez-Caro S, Espinosa de Santillana IA. Asociación entre estructuras craneofaciales de adolescentes y los trastornos temporomandibulares. Revista de Salud Pública. 2015;17:938-950. https://dx.doi.org/10.15446/rsap.v17n6. 34833

5. Contro C, Miller A, Hatcher D, Oberoi S. Evaluating condylar head morphology as it relates to the skeletal vertical facial dimension: A three-dimensional semi-automated landmark study. APOS Trends Orthod 2016;6:238-245. doi:10.4103/2321-1407.190724

6. Gorucu-Coskuner H, Ciger S. Computed tomography assessment of temporomandibular joint position and dimensions in patients with class II division 1 and division 2 malocclusions. J Clin Exp Dent. 2017;9:e417-e423. doi: 10.4317/jced.53524.

7. Espinoza K, Santos N, Chávez M; Relación de los estadios de la osteoartrosis temporomandibular con los cambios dimensionales del espacio articular temporomandibular, evaluados con tomografía computarizada cone beam. Revista Peruana de Investigación en Salud. 2017;1:40-47. doi 10.35839/repis.1.1.201

8. Kuć J, Sierpińska T, Gołębiewska M. Alveolar ridge atrophy related to facial morphology in edentulous patients. Clin Interv Aging. 2017;12:1481-1494. doi: 10.2147/CIA. S140791.

9. Rangel, Heriberto \& Sandoval, Jose \& Rocha, Maira. Medición antropometria orofacial del crecimiento transverso de la mandibula. Rev. Signos Fónicos, 2016-2017; 2:144-160. URL: https://www.researchgate.net/publication/328590140 MEDICION_ANTROPOMETRIA_OROFACIAL_DEL_ CRECIMIENTO_TRANSVERSO_DE_LA_MANDIBULA octubre 2016 / marzo 2017

10. Mickeviciute E, Baltrusaityte A, Pileicikiene G. The relationship between pathological wear of teeth and temporomandibular joint dysfunction. Stomatologija. 2017;19:3-9.

11. Colonna A, Manfredini D, Lombardo L, Muscatello L, Marchese-Ragona R, Arveda N, Siciliani G. Comparative analysis of jaw morphology and temporomandibular disorders: A three-dimension imaging study. Cranio. 2020 May;38:158-167. doi: 10.1080/08869634.2018.1507094.

12. da Cunha DV, Degan V, Vedovello Filho M, Bellomo DP. Real-time three-dimensional jaw tracking in temporomandibular disorders. J Oral Rehabil. 2017;44:580588. doi: 10.1111 joor. 12521 .

13. Quiroga-del Pozo R, Sierra-Fuentes M, del Pozo-Bassic J, Quiroga-Aravenad R. Dimensión vertical oclusal: comparación de 2 métodos cefalométricos. Revista Clínica de Periodoncia, Implantología y Rehabilitación Oral. 2016;9:264-270. https:// scielo.conicyt.cl/pdf/piro/v9n3/art09.pdf

14. Silva-Bersezio R, Schulz-Rosales R, Cerda-Peralta B, Rivera-Rothgaenger M, et al.. Determinación de dimensión vertical oclusal a partir de la estatura y diámetro craneal. Rev Clin Periodoncia Implantol Rehabil Oral. 2015;8:213216. URL: https://dx.doi.org/10.1016/j.piro.2015.06.004

15. Brenes Ortega L, Santamaría Arrieta G, Fernández-González $\mathrm{F}$, Martín Blanco $\mathrm{N}$ et al. Análisis comparativo de la repetibilidad y reproductibilidad de dos métodos de medición de la dimensión vertical en rehabilitación oral: una revisión sistemática. Int J Odontostomat. 2016;10:55-62. URL:https:// dx.doi.org/10.4067/S0718-381X2016000100010
16. Teguh S, Kusdhany L, Koesmaningati H. Facial and Hand Landmark Measurements for Making Accurate Occlusal Vertical Dimension Determinations, J Int Dent Med Res. 2017;10: 696-700. URL: https://pdfs.semanticscholar. org/9d98/3e059e76d201addbd7ec230695fd86b82dde. pdf? ga=2.247326660.1164348083.1585863821-108042 7989.1585863821

17. Talavera M, Meneses A, Comparación de los métodos cráneométricos de Willis y Mc Gee para determinar la dimensión vertical de oclusión en estudiantes universitarios de pregrado de Puno, Rev. estomatol. Altiplano.2014 JulDic; Vol 1 Nro 2. URL: https://www.semanticscholar.org/ paper/Comparaci\%C3\%B3n-de-los-m\%C3\%A9todoscr\%C3\%A1neom\%C3\%A9tricos-de-Willis-TalaveraMeneses/eefed70e6b1c7dd00e2bbcfd0fd6cc8783c54f6e

18. Caregnatto Morais EC, Pick Ornaghi B, Sponchiado AP, Zielak JC, Goulart da Costa R, Fraxino Bindo JM, Alves de Campos E. Determination of final occlusal vertical dimension by cephalometric analysis; RSBO. 2015;12:143-150. URL: http://revodonto.bvsalud.org/scielo.php?script=sci abstract\&pid=S1984-56852015000200001\&lng=pt\&nrm= iss\&tlng $=$ en

19. Enkling N, Enkling-Scholl J, Albrecht D, Bornstein MM, Schimmel M. Determination of the occlusal vertical dimension in edentulous patients using lateral cephalograms. J Oral Rehabil. 2018;45:399-405. doi:10.1111/joor.12624.

20. Yamashita S, Shimizu M, Katada H. A Newly Proposed Method to Predict Optimum Occlusal Vertical Dimension. J Prosthodont. 2015;24:287-290. doi: 10.1111/jopr.12223.

21. Kusdhany L, Indrasari M, Koesmaningati H, Leepel M, Oktaria I. Occlusal vertical dimension index to simplified vertical dimension measurement. Int Dent Med Res 2016;9:334-338. URL: http://www.ektodermaldisplazi. com/journal/Journal2016/Special_Issue/12_D16_34_ Linda_occlusal.pdf

22. Fernández E, Jaramillo P, Gonzalez H, Nakouzi J, Padilla T. Dimensión vertical oclusal mediante antropometría de los dedos de la mano. Validación del método antropométrico de Ladda. Rev. Clin. Periodoncia Implantol. Rehabil. Oral. 2017;10:149-152. URL: http://dx.doi.org/10.4067/S071901072017000300149.

23. Vinnakota DN, Kanneganti K, Pulagam M, Keerthi G. Determination of vertical dimension of oclusion using lateral profile photographs: A pilot study. J Indian Prosthodont Soc 2016;16:323-327. doi: 10.4103/0972-4052.176531

24. Alhajj MN, Khalifa N, Abduo J, Amran AG, Ismail IA. Determination of occlusal vertical dimension for complete dentures patients: an updated review. J Oral Rehabil. 2017;44:896-907. doi: 10.1111/joor.12522.

25. Ladda R, Kasat VO, Bhandari AJ. A new technique to determine vertical dimension of occlusion from anthropometric measurement of interpupillary distance. J Clin Exp Dent. 2014;6:e395-9. doi: 10.4317/jced.51671

26. Sánchez M, Yanez E. Asociación entre el biotipo facial y la sobremordida. Estudio piloto. Rev Estomatol Herediana. 2015; 25:5-11. http://www.scielo.org.pe/scielo.php?script=sci_artt ext\&pid=S1019-43552015000100002\&lng=es

27. Bedoya A, Osorio JC, Tamayo JA. Determining facial biotype based upon phenotypic features through structural equation modeling: a study of three ethnic groups. Rev Fac Odontol Univ Antioq. 2013;25:132-146. URL: http://www. 
scielo.org.co/scielo.php?script $=$ sci arttext\&pid $=$ S0121246X2013000200008\&lng=en

28. Ayoub W, Rashid R. Novel technique to determine vertical dimension of occlusion from interpupillary distance in kashmiri population. IJESC, 2017, 14955-14957.

URL: http://ijesc.org/upload/be93c9f242a22e4118198dd437 30fd63.Novel\%20Technique \%20to\%20Determine $\% 20$ Vertical\%20Dimension\%20of\%20Occlusion\%20from $\% 20$ Interpupillary\%20Distance $\% 20 \mathrm{in} \% 20 \mathrm{Kashmiri} \% 20$ Population.pdf

29. Alhajj MN, Khalifa N, Amran A. Eye-rima oris distance and its relation to the vertical dimension of occlusion measured by two methods: Anthropometric study in a sample of Yemeni dental students. Eur J Dent. 2016;10:29-33. doi: 10.4103/1305-7456.175689.

30. Bajunaid S, Baras B, Alhathlol N, Ghamdi A. Evaluating the reliability of facial and hand measurements in determining the vertical dimension of occlusion. International Journal of Medicine and Pharmacy, 2017;5. doi: 10.15640/ijmp. v5n1a1

31. Majeed MI, Haralur SB, Khan MF, Al Ahmari MA, Al Shahrani NF, Shaik S. An Anthropometric Study of Cranio-Facial Measurements and Their Correlation with Vertical Dimension of Occlusion among Saudi Arabian Subpopulations. Open Access Maced J Med Sci. 2018;6:680-686. doi: 10.3889/oamjms.2018.082.

32. Constantiniuc M, RemeŞ A, Ispas A, Popa D, BACIU S, BACALI C. Reliability of three common methods for determining the vertical dimension of occlusion in completely edentulous patients. International Journal of Medical Dentistry 2019;23. URL:https://www.ijmd. ro/2019/vol-23-issue-2/reliability-of-three-commonmethods-for-determining-the-vertical-dimension-ofocclusion-in-completely-edentulous-patients.

33. Batra R, Kalra S, Bansal A, Nerula S. Estimation of vertical dimension of occlusion in edentuleous patients using cephalometric analysis. Dental Journal of Advance Studies 2017 Vol. 5. doi: 10.1055/s-0038-1672078

34. Ousehal L, Jouhadi E, Bennani A. Vertical dimension of occlusion (VDO): cephalometric norms for a Moroccan population. J Orofac Orthop. 2016;77:39-44. doi: 10.1007/ s00056-015-0006-0.

35. Sierpinska T, Kuc J, Golebiewska M. Morphological and Functional Parameters in Patients with Tooth Wear before and after Treatment. Open Dent J. 2013; 7:55-61. doi: 10.2174/1874210601307010055.

36. Behrensdorf L, Costa Ribeiro R, Britto T, Gonzatti A, Boscato N. Factors associated with mandibular movement and vertical dimension of occlusion in elderly complete-denture wearers. Stomatos, 2016;22:-14. URL: http://revodonto.bvsalud.org/scielo.php?script=sci arttext\&pid=S1519-44422016000100002

37. Fukushima S. A controversy with respect to occlusion. Jpn Dent Sci Rev. 2016; 52:49-53. doi: 10.1016/j. jdsr.2016.02.001.

38. Watarai Y, Mizuhashi F, Sato T, Koide K. Highly producible method for determination of occlusal vertical dimension: relationship between measurement of lip contact position with the closed mouth and area of upper prolabium. J Prosthodont Res. 2018;62:485-489. doi:10.1016/j. jpor.2018.06.005..

39. Miran FA, Determination of relation the between the vertical dimension of occlusion and right hand little finger. J Oral Dent Res 2018;5:22-31. https://www.iasj.net/iasj ?func=fulltext\&aI $\mathrm{d}=145756$.

40. 40.Mahboub F, Kimyai S, Molavi E. Determining the distance from the lingual frenum anterior attachment to the lower incisors' incisal edges. J Dent Res Dent Clin Dent Prospects. 20161;10:257-262. doi: 10.15171/ joddd.2016.041. 